\title{
Genetic Variation for Striga hermonthica Resistance and Yield Among Sorghum Accessions in Nigeria
}

\author{
G. Afolayan ${ }^{1,2}$, S. E. Aladele ${ }^{1}$, S. P. Deshpande ${ }^{3}$, A. O. Kolawole, ${ }^{2,4}$, D. J. Nwosu ${ }^{1}$, C. Michael ${ }^{1}$, \\ E. T. Blay ${ }^{2} \&$ E. Y. Danquah ${ }^{2}$ \\ ${ }^{1}$ National Center for Genetic Resources and Biotechnology (NACGRAB), Nigeria \\ ${ }^{2}$ West African Center for Crop Improvement, University of Ghana, Legon, Ghana \\ ${ }^{3}$ International Crop Research Institute for the Semi-Arid Tropics (ICRISAT), India \\ ${ }^{4}$ Ladoke Akintola University of Technology, Ogbomoso (LAUTECH), Nigeria \\ Correspondence: G. Afolayan, National Center for Genetic Resources and Biotechnology (NACGRAB), Nigeria. \\ E-mail:ogo246@yahoo.com
}

S. P. Deshpande, International Crop Research Institute for the Semi-Arid Tropics (ICRISAT), India. E-mail: s.deshpande@cgiar.org

Received: March 11, 2020

Accepted: May 2, $2020 \quad$ Online Published: June 15, 2020

doi:10.5539/jas.v12n7p192

URL: https://doi.org/10.5539/jas.v12n7p192

\begin{abstract}
Striga hermonthica (Delile) Benth., commonly referred to as witch weed, is a major constraint to sorghum (Sorghum bicolor (L.) Moench) production in the Northern region of Nigeria because of high yield losses due to infestation. To identify parental lines useful in breeding for $S$. hermonthica resistant sorghum genotypes adapted to Nigeria, twenty-five sorghum accessions were evaluated in Nigeria across three test environments. Both phenotypic and genetic components influenced the variation observed in the sorghum accessions. The estimates for the genetic coefficient of variation, heritability and genetic advance for the area under Striga number progress curve (ASUNPC), Striga emergence counts, yield and other agronomic traits, obtained in this study revealed that genetic gain for resistance to $S$. hermonthica could be realized through selection. Based on the performance of the 25 sorghum accessions SRN39, Danyana, Sepon82, and SAMSORG40 were the top four accessions found to be most resistant to $S$. hermonthica. Assessment of resistance was based on the low Striga emergence counts and the ASUNPC values. These accessions can be used as donor sources of S. hermonthica resistant genes for introgression into cultivars adapted to Nigeria, followed by recombination breeding for pyramiding the different resistance mechanisms.
\end{abstract}

Keywords: ASUNPC, constraints, infestation, Striga, witch weed

\section{Introduction}

Sorghum (Sorghum bicolor (L.) Moench) is essential for food security in sub-Saharan Africa (SSA), due to its relative drought tolerance as compared with other cereals (Senthilvel et al., 2008). This is evident from breeding programs in the region that are directing their efforts in developing sorghum varieties that are high yielding, resistant to insect pests and diseases, Striga hermonthica and can also survive in drought-prone environments (Obilana, 2004). These breeding efforts through hybridization and successful selection have led to the development of pure-line cultivars from progenies with suitable adaptation (plant height and maturity), disease resistance and higher yield (Rooney, 2004).

Despite all efforts aimed at the improvement in breeding programs, sorghum yield still remains very low (0.83 $\mathrm{t} / \mathrm{ha}$ ) in sub-Saharan Africa (SSA) (Tadele, 2017), with approximately $1.2 \mathrm{t} / \mathrm{ha}$ in Nigeria (FAOSTAT, 2018). This is attributable to several biotic and abiotic production constraints. The parasitic weed, Striga hermonthica is one of the major biotic constraints to sorghum production in SSA. Striga hermonthica causes damage to its host by extracting water, nutrients and assimilates, thus affecting the host water relations and carbon fixation (Press et al., 1996). Striga hermonthica depends mainly on the host for its survival with its life cycle closely revolving around that of the host plant. The development and deployment of effective host-plant resistance (HPR) is the most feasible option against this parasite (Kountche et al., 2013). 
Several differential resistance mechanisms to $S$. hermonthica by sorghum genotypes, based on field/ glasshouse conditions, have been described by (Haussmann et al., 2000a). Such mechanisms include the production of low germination stimulant, the mechanical prevention of host cell penetration in the form of cell wall lignification, the inhibition of exo-enzymes in the germ tube by root exudates and the synthesis of phytoalexin. Likewise, as described by (Lane et al., 1993), there could be hypersensitive reactions after $S$. hermonthica attachment or incompatibility which may result into the reduction of further growth once the haustorial connection is established. The reduction of Striga development through; antibiosis which is the supply of unsuitable phytohormone by the host, insensitivity to Striga toxin by maintaining the stomatal aperture, photosynthetic efficiency and the inhibition of haustorial formation are other mechanisms of reducing Striga development in host plants (Haussmann et al., 2000a; Ejeta et al., 2000).

The resistance of the various sorghum genotypes can be defined based on field or pot observations with different Striga infection measures indicating the level of resistance. Such measures as described by (Haussmann et al., 2000a) include: (i) number of emerged Striga plants per pot or $\mathrm{m}^{2}$ at $\mathrm{n}$ days after sowing (Sn). Such counts could be done at 2-week intervals starting from 2-3 weeks after the first Striga plant has emerged in the trials. (ii) Number of above-ground Striga plants at harvest (NSharvest); (iii) mean Striga vigor score (Vn). The score is based on the morphological characteristics of the Striga plant by evaluating the mean Striga height and number of branches and is scored at each counting date on a 1-9 scale. The score is important because the effect of Striga plants of $5 \mathrm{~cm}$ height may differ significantly from that of fully-developed $40 \mathrm{~cm}$ Striga plants with numerous branches, flowers, and seed capsules. Another measure is Striga severity index at $\mathrm{n}$ days after sowing (SVn) which is estimated by multiplying the emerged Striga by its respective mean Striga vigor. This resistance measure helps to have a relative assessment of the total Striga biomass in a plot because the evaluation of Striga biomass is a destructive measure that is generally painstaking and commonly has a high error variance (Omanya et al., 2004). Area Under the Above-ground Striga Number Progress Curve (AUSNPC) is another measure. This trait is calculated from the successive emerged Striga counts by adapting the formula for Area Under the Disease Progress Curve, AUDPC (Haussmann et al., 2000a). The AUSNPC accounts for the intensity and speed of the Striga epidemic and the higher the AUSNPC the more susceptible the genotype is. Finally, another measure for resistance evaluation is (iv) the Area Under the Striga Severity Progress Curve (AUSNPC) which can also be estimated using the severity value.

Narrow genetic variability range among accessions of a crop is always disadvantageous because it limits the crop's ability to adapt to or tolerate/resist environmental stresses and epidemics which result in yield loss (Govindaraj et al., 2015). However, there are many wild relatives (National Research Council, 1993), landraces and some improved varieties of crop plants which possess genes influencing resistance to both biotic and abiotic stresses which when introgressed into economically important varieties, could help avert or lessen the issue of yield loss through appropriate breeding schemes. Identification of $S$. hermonthica resistant sorghum accessions will lead to the development of varieties suitable for different agro-ecological zones in Nigeria. Improvement in yield will, in turn, have a significant impact on the livelihoods of farmers thus helping them to reduce poverty as yield security is guaranteed in Striga infested conditions (Rodenburg et al., 2017). In the present study, different African landraces, uncharacterized sorghum accessions which have never been screened for resistance to $S$. hermonthica as well as released sorghum varieties available in Nigeria's national gene bank, farmers preferred varieties and documented $S$. hermonthica resistant sorghum varieties were evaluated to; i) characterize genetic variation for $S$. hermonthica resistance, and ii) identify diverse germplasm in $S$. hermonthica resistance breeding.

\section{Materials and Methods}

\subsection{Experimental Material}

Experimental materials consisted of 25 sorghum accessions, including two $S$. hermonthica resistant lines (N13 and SRN 39) with known resistant mechanisms and validated QTLs (Table 1).

\subsection{Experimental Sites}

These accessions were evaluated at the Institute for Agricultural Research (IAR) Samaru, Zaria (11.17, 7.62, altitude $688 \mathrm{~m}$ ), farmers' fields at Karaukarau, Giwa local government area Kaduna (11.32, 7.38, altitude $679 \mathrm{~m}$ ) and Farmers' field at Mokwa, Niger state $(9.20,5.47$, altitude $331 \mathrm{~m})$. These environments are Striga sick plots in high sorghum producing areas. 


\subsection{Experimental Methods}

The accessions were arranged in $5 \times 5$ alpha lattice design with three replications. An individual variety was grown on two $5 \mathrm{~m}$ rows per plot with $0.75 \mathrm{~m}$ spacing between rows and a $0.3 \mathrm{~m}$ in row spacing. Plots were demarcated by an empty row of $1 \mathrm{~m}$ and a $1.25 \mathrm{~m}$ alley was used to separate each replicate.

The experiments were carried out on S. hermonthica infested fields that were ascertained to be highly infested and which had been used repeatedly for $S$. hermonthica research. However, to avoid the case of heterogeneity of natural field infestations, artificial $S$. hermonthica infestation of each planting hill was done at a depth of $10 \mathrm{~cm} . S$. hermonthica seeds used was mixed with finely sieved soil at $30 \mathrm{~g}$ of Striga seeds per $2000 \mathrm{~g}$ of soil and $2.5 \mathrm{~g}$ of the mixture was used for infestation per planting hill. In each of the trials, sorghum was sown at 6 seeds per planting hill and was thinned to 2 plants per hill, 25 days after sowing (DAS). Throughout the experiments, all trials were frequently hand weeded between 2 to 3 weeks to eliminate all weeds except $S$. hermonthica. Fertilizer application was done at the rate of $60 \mathrm{~kg} / \mathrm{ha}$ of NPK 15-15-15 at 4 weeks after sowing and all agronomic practices for sorghum were carried out.

\subsection{Collection of Agronomic and Striga Resistant Data}

Data were recorded on days to $50 \%$ flowering (DTF), Plant height (PH), number of panicles harvested per plot (Head count: HC), the weight of harvested panicle (HW) after drying, grain weight after threshing (GW) and grain yield (GY). The number of Striga plants per plot was obtained by counting all the emerged Striga plants in each plot, Striga emergence counts (STC) were taken at two weeks intervals starting from 45 days after sowing. Emerged Striga counts at 45,59 and 73 days after sowing were recorded at the three environments.

\subsection{Data Analysis}

Analysis of variance (ANOVA) was conducted on plot means for all traits measured for each of the environment separately followed by combined analysis across environments using the PROC GLM in SAS (K. A. Gomez \& A. A. Gomez 1984; SAS Institute, 2010). The analysis from the three environments shows moderate heritability estimates and low coefficient of variation for all traits measured (data not shown) thereby justifying the analysis across the environments. In order to satisfy the rule of the normal distribution, a logarithmic transformation $\left[\log _{10}(\mathrm{X}+\mathrm{c})\right]$, where, $X$ is the original, individual count and $c=1.0$, according to (Rodenburg, 2005) was applied to the emerged Striga count data before conducting ANOVA. The Area Under Striga Number Progress Curve (AUSNPC) which is a degree of the total Striga emergence during the growing season, as defined by (Rodenburg, 2005) was estimated with the transformed data as

$$
\operatorname{AUSNPC}=\sum_{\mathrm{i}=0}^{\mathrm{n}-1}\left[\mathrm{Si}+\frac{\mathrm{S}_{(+1)}}{2}\right]\left[\mathrm{t}_{(\mathrm{i}+1)}-\mathrm{t}_{\mathrm{i}}\right]
$$

where, $\mathrm{n}=$ the number of days at which Striga was counted, $\mathrm{Si}=$ the Striga number at the $i^{\text {th }}$ assessment date, $\mathrm{t}_{\mathrm{i}}=$ the number of days after sowing at the $i^{\text {th }}$ assessment date.

Entry means adjusted for block effects according to the lattice design (Cochran \& Cox, 1960) were generated for each trait across environments. A rank summation index (RSI) (Mulumba \& Mock, 1978) was constructed to create the aggregate trait by ranking the lines with regard to high grain yield, $S$. hermonthica resistance, and improved agronomic performance. The 25 accessions were ranked from lowest to highest for each trait and RSI was calculated by summing the ranks. The ranks were summed for each accession to select the top ten outstanding sorghum accessions. An accession with the least number for days to 50\% flowering, AUSNPC, Striga emergence count at 45, 59 and 73 DAS and the highest number for grain yield, ranks first for RSI.

Expectations of mean squares (EMS) from analysis of variance were used to estimate phenotypic $\left(\sigma^{2} p\right)$ and genotypic $\left(\sigma^{2} \mathrm{~g}\right)$ variances according to (Keneni \& Jarso, 2009). Phenotypic (PCV) and genotypic (GCV) coefficients of variation were derived using the formula of (Allard, 1960):

$$
\mathrm{PCV}=\frac{\sqrt{\sigma^{2}}}{\text { Grand mean }} \times 100
$$

and,

$$
\mathrm{GCV}=\frac{\sqrt{\sigma^{2} \mathrm{~g}}}{\text { Grandmean }} \times 100
$$

Broad sense heritability $\left(\mathrm{h}^{2}\right)$ was estimated according to (Johnson et al., 1955) by the formula:

$$
h^{2}=\frac{\sigma^{2} g}{\sigma^{2} p}
$$

where, $\sigma^{2} p=$ phenotypic variance and $\sigma^{2} p=$ genotypic variance. 
The heritability percentage was categorized as low, moderate and high, similar to that of (Robinson et al., 1949) as follows: $<50 \%=$ low; $50 \%=$ moderate and $>50 \%=$ high. Genetic advance expressed as a percent of the mean supposing a selection intensity of 5\% were also calculated using the formula of (Robinson et al., 1949) as follows:

$$
\begin{gathered}
\mathrm{GA}=\mathrm{K} \frac{\sigma^{2} \mathrm{~g}}{\sqrt{\sigma^{2} \mathrm{p}}} \\
\mathrm{GA} \%(\mathrm{GA} \text { as } \% \text { of the mean })=\frac{\mathrm{GA}}{\text { grandmean }} \times 100
\end{gathered}
$$

where, $k$ represents the standardized selection differential which was 2.06 at $5 \%$ selection differential and it was 2.06 as defined by (Lush, 1949), $\sigma_{\mathrm{g}}^{2}$ is the genetic variance, and $\sqrt{ } \sigma^{2} \mathrm{p}$ denotes phenotypic standard deviation. Pearson's correlation analysis was done to determine the associations among grain yield and other measured agronomic traits with SAS (SAS Institute, 2010).

\section{Results}

\subsection{Performance of Sorghum Accessions Across Test Environments}

The combined ANOVA for data collected under artificial S. hermonthica infestation evaluated across three environments showed that the environment was an important source of variation for all traits measured except for grain weight and yield (Table 2). The 25 sorghum accessions and accessions $\times$ environment interaction mean squares were highly significant $(P<0.001)$ for yield-related traits, number of days to $50 \%$ flowering and plant height, except for Striga emergence counts at 45, 59 and 73 days after sowing and AUSNPC. Across the environments, average grain yield and other yield-related traits values were highest at IAR-Zaria. The sorghum accessions grew taller at Giwa-Kaduna and flowered earliest at Mokwa-Niger. The range of Striga emergence counts at 45, 59 and 73 days after sowing across environments was 0.17 to 2.43 and Mokwa-Niger had the highest average count of 1.40 at 73 days after sowing (Table 3). Average AUSNPC of the accessions ranged from 0.41 to 60.92. Higher Striga infestation was observed at IAR-Zaria with an average AUSNPC of 34.10.

\subsection{Performance of Outstanding Sorghum Accessions Across the Test Environments}

The mean grain yield of the 25 sorghum accessions evaluated under artificial S. hermonthica infestation ranged from $1065.60 \mathrm{~kg} \mathrm{ha}^{-1}$ for Sariaso 14 to $4233.84 \mathrm{~kg} \mathrm{ha}^{-1}$ for SAMSORG 14 (Appendix A). From the list of the outstanding sorghum accessions, lowest Striga emergence count was recorded across environments for SRN39 and Sepon82, but with low grain yield (Table 4). Also, farmers' preferred variety (SAMSORG 40) and NGJD0511063 an accession collected from the national gene-bank of Nigeria had low Striga emergence count. Danyana was ranked as the most promising accession with a lower level of Striga emergence count combined with high grain yield. The AUSNPC being one the most discriminative measure of resistance gives a degree of the entire Striga growth and the level of infestation on its hosts over the growing season. On average, the accessions SRN39 and Sepon82 had the lowest AUSNPC across the environments.

\subsection{Genetic Variability Among Sorghum Accessions}

The phenotypic variances were larger than the genotypic variances for all the traits measured (Table 5). Grain yield and plant height had the highest phenotypic and genotypic variances. Striga emergence count at 45, 59 and 73 days after sowing and AUSNPC had low values for phenotypic and genotypic variances with heritability estimates ranging from 21-32\%. Broad sense heritability estimates were high (i.e., $>50 \%$ ) for head weight, grain weight, grain yield, plant height and days to 50\% flowering. However, Striga resistance traits reflect lower broad-sense heritability estimates. The Genetic advance as a percentage of the mean ranged from $0.30 \%$ for head count to $39.63 \%$ for grain yield.

\subsection{Phenotypic Correlation}

Traits with similar physiology were highly correlated; grain weight was significantly $(P<0.001)$ correlated with head count and height weight. Grain yield had strong positive correlation $(P<0.001)$ with head count, head weight, and grain weight. There was a strong and positive $(P<0.001)$ relationship between AUSNPC and Striga emergence count at 45, 59 and 73 days after sowing (Table 6). The significant $(P<0.01)$ correlations between Striga emergence count after sowing with head count, number of days to $50 \%$ flowering and plant height were rather weak. A negative significant correlation $(P<0.05)$ was recorded between Striga emergence count at 73 days after sowing and plant height. There was no significant correlation between grain yield and Striga emergence count at 45, 59 and 73 days after sowing and AUSNPC. 
Table 1. Description of sorghum accessions evaluated

\begin{tabular}{|c|c|c|c|}
\hline S. no. & Accession & Source & Comment \\
\hline 1 & NGAA0311016 & NACGRAB, Nigeria & Local collections, unknown resistance \\
\hline 2 & NGOJMAY09009 & NACGRAB, Nigeria & Local collections, unknown resistance \\
\hline 3 & NGSA07143 & NACGRAB, Nigeria & Local collections, unknown resistance \\
\hline 4 & NGSA07103 & NACGRAB, Nigeria & Local collections, unknown resistance \\
\hline 5 & NGJD0511063 & NACGRAB, Nigeria & Local collections, unknown resistance \\
\hline 6 & NGAO1108001 & NACGRAB, Nigeria & Local collections, unknown resistance \\
\hline 7 & SAMSORG 14 & Nigeria & Improved variety, tolerant to Striga \\
\hline 8 & SAMSORG 40 & Nigeria & Improved variety, Susceptible to Striga \\
\hline 9 & Danyana & Nigeria & Farmers variety, late maturing, unknown resistance \\
\hline 10 & CSR-01 & Nigeria & Improved variety, High malting quality, unknown resistance \\
\hline 11 & CSR-02 & Nigeria & Improved variety, High malting quality, unknown resistance \\
\hline 12 & SAMSORG 39 & Nigeria & Improved variety, Susceptible to Striga \\
\hline 13 & SRN 15401 & Nigeria & Improved variety, unknown resistance \\
\hline 14 & N13 & ICRISAT, Mali & Striga resistance \\
\hline 15 & SRN39 & ICRISAT, Mali & Striga resistant-LGS-Sudan \\
\hline 16 & White Kaura & ICRISAT, Mali & Unknown resistance \\
\hline 17 & MaceDaKunya & ICRISAT, Mali & Late-season dune sorghum-Niger, unknown resistance \\
\hline 18 & Wassa & ICRISAT, Mali & Food-grade guinea-Mali, unknown resistance \\
\hline 19 & Malisor 84-7 & ICRISAT, Mali & Food-grade-Mali, unknown resistance \\
\hline 20 & CSM-63 & ICRISAT, Mali & Popular Guinea-Mali, unknown resistance \\
\hline 21 & Grinkan & ICRISAT, Mali & Food Grade Guinea-Mali, unknown resistance \\
\hline 22 & Framida & ICRISAT, Mali & Striga resistant-Burkina Faso \\
\hline 23 & Sepon82 & ICRISAT, Mali & Food-grade-Niger, unknown resistance \\
\hline 24 & Sariaso14 & ICRISAT, Mali & Striga resistant-LGS-Burkina Faso \\
\hline 25 & Seguetana & ICRISAT, Mali & Food-grade guinea-Mali, unknown resistance \\
\hline
\end{tabular}

Table 2. Mean squares of $S$. hermonthica resistance and other agronomic traits of sorghum accessions evaluated across three environments in Nigeria

\begin{tabular}{|c|c|c|c|c|c|c|c|c|c|c|c|}
\hline Source & $\mathrm{df}$ & Head-Count & $\begin{array}{l}\text { Head } \\
\text { Weight } \\
(\mathrm{kg})\end{array}$ & $\begin{array}{l}\text { Grain } \\
\text { Weight } \\
(\mathrm{Kg})\end{array}$ & $\begin{array}{l}\text { Grain } \\
\text { Yield } \\
\left(\mathrm{kg} \mathrm{ha}^{-1}\right)\end{array}$ & $\begin{array}{l}\text { Days } \\
\text { to } 50 \% \\
\text { flowering }\end{array}$ & $\begin{array}{l}\text { Plant } \\
\text { Height } \\
(\mathrm{cm})\end{array}$ & $\begin{array}{l}\text { Striga } \\
\text { emergence } \\
\text { count at } \\
45 \text { DAS }\end{array}$ & $\begin{array}{l}\text { Striga } \\
\text { emergence } \\
\text { count at } \\
59 \text { DAS }\end{array}$ & $\begin{array}{l}\text { Striga } \\
\text { emergence } \\
\text { count at } \\
73 \text { DAS }\end{array}$ & AUSNPC \\
\hline Environment (Env) & 2 & $1530.59^{* * *}$ & $4.04^{*}$ & 0.20 & 1778403 & $5064.23^{* * *}$ & $189033.83^{* * *}$ & $5.55^{* * *}$ & $1.73^{*}$ & $2.51^{* *}$ & $1107.41^{* *}$ \\
\hline Replication (Rep) (Env) & 6 & 106.63 & 0.42 & 0.27 & 2390860 & 145.83 & 3254.02 & 0.24 & 0.13 & 0.16 & 105.63 \\
\hline Block $($ Rep $\times$ Env $)$ & 36 & $111.63^{*}$ & $0.54^{*}$ & 0.18 & 1573857 & 73.65 & $2825.07^{* *}$ & $0.31^{* * *}$ & $0.30^{* * *}$ & $0.23^{* *}$ & $209.96^{* *}$ \\
\hline Accessions & 24 & 175.03 & $1.33^{* *}$ & $0.71^{* *}$ & $6306471^{* * *}$ & $845.39^{* *}$ & $24911.87^{* * *}$ & 0.22 & 0.29 & 0.24 & 189.47 \\
\hline Accessions $\mathrm{x}$ Env & 48 & $176.40^{* * *}$ & $0.57^{* *}$ & $0.30^{* * *}$ & $2602801^{* *}$ & $326.63^{* * *}$ & $6673.38^{* * *}$ & 0.15 & 0.20 & 0.15 & 128.65 \\
\hline Error & 102 & 73.41 & 0.32 & 0.14 & 1260528 & 99.35 & 1504.53 & 0.14 & 0.14 & 0.12 & 90.11 \\
\hline $\mathrm{CV}$ & & 36.14 & 45.55 & 43.93 & 43.93 & 11.25 & 17.21 & 41.48 & 33.14 & 27.68 & 31.62 \\
\hline
\end{tabular}

Note. ${ }^{*},{ }^{* *},{ }^{* * *}$ Significant at $0.05,0.01$ and 0.001 probability levels, respectively. AUSNPC $=$ Area Under Striga Number Progress Curve, DAS $=$ Days after sowing. 
Table 3. Mean performance of the sorghum accessions for grain yield, S. hermonthica emergence counts, AUSNPC and other agronomic traits at three different environments in Nigeria

\begin{tabular}{|c|c|c|c|c|c|c|c|c|c|c|c|c|c|c|c|}
\hline \multirow{2}{*}{ Environments } & \multicolumn{3}{|c|}{ Head Count } & \multicolumn{3}{|c|}{ Head Weight (kg) } & \multicolumn{3}{|c|}{ Grain Weight $(\mathrm{Kg})$} & \multicolumn{3}{|c|}{ Grain Yield $\left(\mathrm{kg} \mathrm{ha}^{-1}\right)$} & \multicolumn{3}{|c|}{ Plant Height $(\mathrm{cm})$} \\
\hline & Min. & Max. & Mean & Min. & Max. & Mean & Min. & Max. & Mean & Min. & Max. & Mean & Min. & Max. & Mean \\
\hline IAR-ZARIA & 10.46 & 40.96 & 28.71 & 0.43 & 3.10 & 1.51 & 0.27 & 1.95 & 0.93 & 807.83 & 5805.08 & 2771.83 & 124.75 & 332.08 & 236.51 \\
\hline GIWA-KADUNA & 1.79 & 46.55 & 19.51 & 0.02 & 2.64 & 1.20 & 0.11 & 1.83 & 0.82 & 337.66 & 5450.28 & 2454.37 & 133.25 & 480.51 & 269.67 \\
\hline MOKWA-NIGER & 0.26 & 42.64 & 22.84 & 0.34 & 1.44 & 0.99 & 0.03 & 1.40 & 0.81 & 100.88 & 4178.39 & 2420.48 & 73.88 & 334.75 & 169.88 \\
\hline $\operatorname{LSD}(5 \%)$ & & & 12.73 & & & 0.96 & & & 0.64 & & & 1892.45 & & & 62.45 \\
\hline \multirow[t]{2}{*}{ Environments } & \multicolumn{3}{|c|}{ Days to $50 \%$ flowering } & \multicolumn{3}{|c|}{$\begin{array}{c}\text { Striga emergence } \\
\text { count at } 45 \text { DAS }\end{array}$} & \multicolumn{3}{|c|}{$\begin{array}{l}\text { Striga emergence } \\
\text { count at 59 DAS } \\
\end{array}$} & \multicolumn{3}{|c|}{$\begin{array}{c}\text { Striga emergence } \\
\text { count at } 73 \text { DAS } \\
\end{array}$} & \multicolumn{3}{|c|}{ AUSNPC } \\
\hline & Min. & Max. & Mean & Min. & Max. & Mean & Min. & Max. & Mean & Min. & Max. & Mean & Min. & Max. & Mean \\
\hline IAR-ZARIA & 77.29 & 121.41 & 95.55 & 1.01 & 1.41 & 1.17 & 1.10 & 1.48 & 1.28 & 1.16 & 1.50 & 1.32 & 29.61 & 39.6 & 34.10 \\
\hline GIWA-KADUNA & 76.34 & 126.06 & 91.08 & 0.69 & 1.11 & 0.91 & 0.78 & 1.09 & 0.96 & 0.91 & 1.16 & 1.04 & 21.38 & 30.09 & 26.18 \\
\hline MOKWA-NIGER & 38.27 & 106.66 & 79.03 & 0.29 & 1.87 & 0.62 & 0.17 & 2.20 & 1.12 & 0.50 & 2.43 & 1.40 & 0.41 & 60.92 & 29.79 \\
\hline $\operatorname{LSD}(5 \%)$ & & & 9.93 & & & 0.30 & & & 0.24 & & & 0.22 & & & 6.30 \\
\hline
\end{tabular}

Note . Min $=$ Minimum, Max $=$ Maximum, AUSNPC $=$ Area Under Striga Number Progress Curve, DAS $=$ Days after sowing

Table 4. Means of outstanding sorghum accessions and rank summation index of grain yield and its agronomic components

\begin{tabular}{llllllll}
\hline Accession & $\begin{array}{l}\text { Grain Yield } \\
\left(\mathrm{kg} \mathrm{ha}^{-1}\right)\end{array}$ & $\begin{array}{l}\text { Days to 50\% } \\
\text { flowering }\end{array}$ & $\begin{array}{l}\text { Striga } \\
\text { emergence } \\
\text { count at } \\
\text { 45 DAS }\end{array}$ & $\begin{array}{l}\text { Striga } \\
\text { emergence } \\
\text { count at } \\
\text { 59 DAS }\end{array}$ & $\begin{array}{l}\text { Striga } \\
\text { emergence } \\
\text { count at } \\
73 \text { DAS }\end{array}$ & AUSNPC & $\begin{array}{l}\text { Rank } \\
\text { summation } \\
\text { index }\end{array}$ \\
\hline SRN39 & $1689.08 \pm 451.25$ & $70.56 \pm 3.88$ & $0.60 \pm 0.14$ & $0.68 \pm 0.14$ & $0.93 \pm 0.13$ & $19.53 \pm 3.68$ & 31 \\
Danyana & $4077.76 \pm 468.95$ & $92.96 \pm 3.85$ & $0.68 \pm 0.14$ & $0.94 \pm 0.14$ & $0.91 \pm 0.13$ & $23.59 \pm 3.67$ & 32 \\
Sepon82 & $2083.17 \pm 498.38$ & $94.09 \pm 4.25$ & $0.57 \pm 0.15$ & $0.63 \pm 0.15$ & $0.92 \pm 0.14$ & $18.63 \pm 3.73$ & 36 \\
SAMSORG40 & $1589.17 \pm 455.70$ & $80.45 \pm 3.91$ & $0.65 \pm 0.15$ & $0.88 \pm 0.14$ & $1.00 \pm 0.14$ & $23.18 \pm 3.70$ & 42 \\
Grinkan & $2640.10 \pm 449.33$ & $87.47 \pm 3.89$ & $0.80 \pm 0.15$ & $1.01 \pm 0.14$ & $1.09 \pm 0.13$ & $26.67 \pm 3.69$ & 49 \\
CSM63 & $1871.81 \pm 498.18$ & $89.95 \pm 3.91$ & $0.79 \pm 0.15$ & $1.00 \pm 0.15$ & $1.09 \pm 0.14$ & $26.44 \pm 3.72$ & 52 \\
NGJD0511063 & $2898.24 \pm 475.42$ & $102.53 \pm 3.87$ & $0.67 \pm 0.14$ & $0.97 \pm 0.14$ & $1.14 \pm 0.13$ & $25.52 \pm 3.66$ & 53 \\
MaceDaKunya & $3971.42 \pm 438.90$ & $94.56 \pm 3.84$ & $0.82 \pm 0.14$ & $1.04 \pm 0.14$ & $1.20 \pm 0.13$ & $27.95 \pm 3.65$ & 58 \\
Framida & $2292.50 \pm 435.07$ & $78.28 \pm 3.83$ & $0.86 \pm 0.14$ & $1.17 \pm 0.14$ & $1.26 \pm 0.13$ & $30.54 \pm 3.64$ & 61 \\
NGSA07103 & $1998.14 \pm 441.06$ & $90.63 \pm 3.86$ & $0.86 \pm 0.14$ & $1.02 \pm 0.14$ & $1.18 \pm 0.13$ & $27.90 \pm 3.67$ & 63 \\
\hline NOte. AUSNPC & A & &
\end{tabular}

Note. AUSNPC $=$ Area Under Striga Number Progress Curve, DAS = Days after sowing.

Table 5. Means, estimates of genetic variance, phenotypic variance, genotypic and phenotypic coefficient of variation, broad-sense heritability and genetic advance for grain yield and its agronomic components

\begin{tabular}{|c|c|c|c|c|c|c|c|}
\hline \multirow{2}{*}{ Traits } & \multirow{2}{*}{ Mean } & \multicolumn{2}{|c|}{ Variances } & \multicolumn{4}{|c|}{$\%$} \\
\hline & & $\sigma^{2} g$ & $\sigma^{2} p$ & PCV & GCV & $\mathbf{H}^{2}(\%)$ & GA \\
\hline Head Count & 23.71 & 0.15 & 19.45 & 18.60 & 1.64 & 0.78 & 0.30 \\
\hline Head Weight (kg) & 1.24 & 0.08 & 0.15 & 31.00 & 23.43 & 57.14 & 36.49 \\
\hline Grain Weight (Kg) & 0.86 & 0.05 & 0.08 & 32.66 & 24.82 & 57.75 & 38.85 \\
\hline Grain Yield $\left(\mathrm{kg} \mathrm{ha}^{-1}\right)$ & 2555.49 & 411518.82 & 700718.96 & 32.76 & 25.10 & 58.73 & 39.63 \\
\hline Days to $50 \%$ flowering & 88.60 & 57.64 & 93.93 & 10.94 & 8.57 & 61.36 & 13.83 \\
\hline Plant Height (cm) & 225.35 & 2026.50 & 2767.99 & 23.35 & 19.98 & 73.21 & 35.21 \\
\hline Striga emergence count at 45 days after sowing & 0.90 & 0.01 & 0.02 & 17.37 & 8.28 & 22.73 & 8.13 \\
\hline Striga emergence count at 59 days after sowing & 1.12 & 0.01 & 0.03 & 16.03 & 7.29 & 20.69 & 6.83 \\
\hline Striga emergence count at 73 days after sowing & 1.25 & 0.01 & 0.03 & 13.06 & 6.53 & 25.00 & 6.73 \\
\hline Area Under Striga Number Progress Curve & 30.02 & 6.76 & 21.05 & 15.28 & 8.66 & 32.11 & 10.11 \\
\hline
\end{tabular}

Note. $\sigma^{2} \mathrm{~g}=$ genotypic variance, $\sigma^{2} \mathrm{p}=$ phenotypic variance, $\mathrm{GCV}=$ genotypic coefficient of variation, $\mathrm{PCV}=$ phenotypic coefficient of variation, $\mathrm{H}^{2}(\%)$ = heritability in the broad sense given as a percentage, $\mathrm{GA}=$ genetic advance as percentage of mean. 
Table 6. Correlation coefficients of grain yield and its agronomic components across environments

\begin{tabular}{|c|c|c|c|c|c|c|c|c|c|c|}
\hline & HC & HW & GW & GY & DTF & $\begin{array}{l}\mathbf{P H} \\
\end{array}$ & STC45 & STC59 & STC73 & AUSNPC \\
\hline $\mathrm{HC}$ & & $0.66^{* * *}$ & $0.68^{* * *}$ & $0.68^{* * *}$ & $0.14^{*}$ & 0.03 & $0.17^{* *}$ & $0.18^{* *}$ & $0.16^{*}$ & $0.18^{* *}$ \\
\hline HW & & & $0.92^{* * *}$ & $0.92^{* * *}$ & $0.36^{* * *}$ & $0.29^{* * *}$ & 0.12 & 0.07 & 0.00 & 0.06 \\
\hline GW & & & & $1.00^{* * *}$ & $0.30^{* * *}$ & $0.29^{* * *}$ & 0.05 & 0.07 & 0.04 & 0.06 \\
\hline GY & & & & & $0.30^{* * *}$ & $0.29^{* * *}$ & 0.05 & 0.07 & 0.04 & 0.06 \\
\hline DTF & & & & & & $0.38^{* * *}$ & $0.14^{*}$ & 0.03 & -0.09 & 0.02 \\
\hline PH & & & & & & & $0.16^{* *}$ & -0.01 & $-0.14^{*}$ & -0.01 \\
\hline STC45 & & & & & & & & $0.75^{* * *}$ & $0.60^{* * *}$ & $0.83^{* * *}$ \\
\hline STC59 & & & & & & & & & $0.89^{* * *}$ & $0.98^{* * *}$ \\
\hline STC73 & & & & & & & & & & $0.92^{* * *}$ \\
\hline AUSNPC & & & & & & & & & & \\
\hline
\end{tabular}

Note. ${ }^{*}, * *, * *$ Correlation coefficient (r) significant at $0.05,0.01$ and 0.001 probability levels, respectively. $\mathrm{HC}$ = head count: number of sorghum panicles harvested per plot, $\mathrm{HW}=$ head weight: weight of harvested sorghum panicles after drying, $\mathrm{GW}=$ grain weight of harvested sorghum panicles; GY = grain yield, DTF = number of days to $50 \%$ flowering; $\mathrm{PH}=$ plant height, STC45, STC59, STC73 = Striga emergence count at 45, 59 and 73 days after sowing, AUSNPC = Area Under Striga Number Progress Curve.

\section{Discussion}

The large and significant environment mean squares for Striga resistance indices in this study depict variability in the test environments. Thus, testing of the sorghum accessions in several environments will help in identifying Striga resistance and high yielding varieties. Diverse genetic background accounts for the significant differences observed in yield related traits, number of days to $50 \%$ flowering and plant height. The non-significant difference for Striga emergence count at 45,59 and 73 days after sowing and AUSNPC confirms tolerance to Striga in most of the sorghum accessions evaluated. Additionally, N13 and SRN 39 have been reported as resistant to S. hermonthica (Haussman et al., 2004; Satish et al., 2012). Highly significant accessions $\mathrm{x}$ environment interactions identified in this study for studied traits with exception of Striga resistance traits, indicates the ability of the experimental sites to discriminate the accessions evaluated. As the performance of the accessions were not consistent under the three environments, possibly because of the differences in the environmental factors. Our result is in agreement with Robert (2011) who reported non-significant genotype by environment interaction effect for all Striga resistance parameters measured in spite of the highly significant differences between the environments of evaluation for Uganda sorghum accessions.

Following the equation given by (Rodenburg et al., 2005), the individual Striga emergence counts were converted into the area under Striga number progress curve (AUSNPC) which is an excellent measure used in describing the degree of Striga emergence on the field throughout the growing season. According to (Hausmann et al., 2001), genotypes having low values for AUSNPC are classified as resistant to Striga while on the other hand, those with high values are susceptible. The performance of the 25 sorghum accession under artificial Striga infestation shows that SRN 39, Danyana, Sepon 82 and SAMSORG 40 combined lower values for Striga emergence counts and AUSNPC which are a useful index for Striga resistance. SRN39 was selected as most resistant to Striga infestation based on the low AUSNPC but had a relatively low yield. This corroborates the findings of (Press et al., 1996; Robert, 2011). However, the resistance nature of SRN39 in the present research was expressed more under low Striga pressure. The resistance of SRN39 has been described to be in the production of low germination stimulant which is conferred by a single major gene, $\lg s$ with a recessive mode of inheritance (Gobena et al., 2017). Nevertheless, such single-gene mechanism of Striga resistance is not enough to prevent infestation when the amount of Striga seed present in the soil is very high. Therefore relying on resistance conferred by a single mechanism and single gene is likely to prove risky when using host plant resistance to control a highly variable and allogamous noxious weed such as Striga hermonthica (Rodenburg \& Bastiaans, 2011; Yoder \& Scholes, 2010). On the other hand, the resistance nature of these outstanding sorghum accessions may be exploited in backcross breeding.

Gobena et al. (2017) and Satish et al. (2012) have tagged and validated microsatellite markers linked to the $\lg s$ gene in different sorghum accessions including SRN39. Since the low Striga germination stimulant activity is a unique resistance mechanism in sorghum, it shows that such markers could be successfully used for marker-assisted breeding to boost Striga resistance in sorghum. This suggests that SRN39 could be used as a 
donor parent to successfully introgress the low stimulant resistance trait into new and existing sorghum varieties in Nigeria.

The difference between phenotypic and genotypic coefficient of variation expressed in percentage for all traits measured ranged between 14-91\%, which is a reflection of high environmental influence on the traits measured. This trend was earlier reflected in the ANOVA by the high environment mean squares. Lower phenotypic and genotypic coefficient of variation and genetic advance observed for Striga emergence counts at 45, 59 and 73 days after sowing and AUSNPC in comparison to other traits measured in this study implies low genetic variation among the sorghum accessions for those traits. High broad-sense heritability estimates observed for head weight, grain weight, grain yield, plant height and days to $50 \%$ flowering depicts that these traits were quantitatively inherited, indicating the presence of additive gene action. Thus, there is adequate variation for further improvement of these traits, which may be exploited to obtain further breeding gains. The lower broad-sense heritability estimates for AUSNPC and Striga emergence counts at 45, 59 and 73 days after sowing indicate that the genetic variation was a small and genetic gain for those traits will be slow because both genetic and phenotypic constituents of the accessions are affected by Striga infestation stress. Moderate genetic advance for yield-related traits and plant height indicate the possibility for progress from the selection. Similarly, Robert (2011) reported low heritability estimate and genetic advance for Striga resistance related traits. However, high estimates of broad-sense heritability and genetic advance for all measured traits in sorghum has been reported previously by (Warkad et al., 2008; Haussmann et al., 2000b). Thus, the results of this study showed that genetic variation exists among the African sorghum accessions, indicating the opportunities to explore these differences through genetic crop improvement with the intention of reducing yield losses obtained from biotic stresses such as Striga. According to (Dhliwayo \& Pixley, 2003), such genetic variability is normally used for the introgression of important traits that are deficient in elite crop varieties via conventional breeding and molecular breeding approaches.

Furthermore, our results showed that traits with similar basic physiology were highly associated. The significantly high association between grain yield and head count, head weight, grain weight implies that may be considered as a secondary trait when selecting for improved grain yield in sorghum breeding. In contrast, Striga emergence counts at 45, 59 and 73 days after sowing and AUSNPC were not correlated with grain yield, suggesting that they are not reliable parameters for the detection of improved grain yield. The negative and weak correlation between Striga emergence counts at 73 days after sowing and plant height suggested that taller plants gave lower Striga emergence count. Similarly, Omanya et al. (2004) reported a negative correlation between the AUSNPC and plant height, thus revealing the impact of Striga infestation on sorghum plant resulting in stunted growth which could, in turn, affect the entire crop yield. The strong correlation between Striga emergence count and AUSNPC indicate that either of the parameters will be sufficient as a selection criterion. Information on the correlation of traits among the sorghum accessions will aid selection index in sorghum varietal improvement programs.

In conclusion, the genetic variability observed among the 25 sorghum accessions evaluated could be exploited by sorghum breeders to boost the efficiency of sorghum improvement programs. Nonetheless, further studies are needed to identify stable and high yielding sorghum accessions resistant to $S$. hermonthica across multiple environments over years. These accessions may then be selected as parental lines which are useful in sorghum improvement programs in Nigeria.

\section{Acknowledgements}

This work has been undertaken as part of a Ph.D. research funded by the Alliance for Green Revolution in Africa (AGRA) through the West African Centre for Crop Improvement (WACCI). Also as part of CGIAR Research Program (CRP) on Grain Legumes and Dryland Cereals. The authors would like to thank the West African Centre for Crop Improvement (WACCI) for excellent supervision. Also technical and advisory support from the CGIAR Research Program (CRP) on Grain Legumes and Dryland Cereals is highly appreciated. The provision of Sorghum germplasm by the National Center for Genetic Resources and Biotechnology (NACGRAB), Institute for Agricultural Research (IAR) Nigeria and International Crop Research Institute for Semi-Arid Tropics (ICRISAT) Mali and Kenya, is gratefully acknowledged.

\section{References}

Allard, R. W. (1960). Principles of Plant Breeding. John Willey and Sons, New York.

Cochran, W. C. \& Cox, C. K. (1960). Experimental Design. John Wiley and Sons, Incorporated New York, USA. 
Dhliwayo, T., \& Pixley, K. V. (2003). Divergent selection for resistance to maize weevil in six maize populations. Crop Science, 43, 2043-2049. https://doi.org/10.2135/cropsci2003.2043

Ejeta, G., Mohammed, A., Rich, P., Melake-Berhan, A., Housley, T. L., \& Hess, D. E. (2000). Selection for specific mechanisms of resistance to Striga in sorghum. Breeding for Striga resistance in cereals (pp. 29-37). MargrafVerlag, Weikersheim.

FAOSTAT. (2018), Retrieved May 26, 2019, from http://www.fao.org/faostat/en/\#data/QC

Gobena, D., Shimels, M., Richa, P., Ruyter-Spirab, C., Bouwmeesterb, H., Kanugantia, S., ... Ejeta. G. (2017). Mutation in sorghum low germination stimulant alters strigolactones and causes Striga resistance. PNAS, 114(17), 4471-4477. https://doi.org/10.1073/pnas.1618965114

Gomez, K. A., \& Gomez, A. A. (1984). Statistical Procedures for Agricultural Research (pp. 8-76). New York: John Wiley \& Sons.

Govindaraj, M., Vetriventhan, M., \& Srinivasan, M. (2015). Importance of genetic diversity assessment in crop plants and its recent advances: an overview of its analytical perspectives. Genetics Research International, 2015, Article ID 431487. https://doi.org/10.1155/2015/431487

Haussmann, B. I. G., Hess, D. E., Omanya, G. O., Folkertsma, R. T., Reddy, B. V. S., Kayentao, M., ... Geiger, H. H. (2004). Genomic regions influencing resistance to the parasitic weed Striga hermonthica in two recombinant inbred populations of sorghum. Theoretical and Applied Genetics, 109(5), 1005-1016. https://doi.org/10.1007/s00122-004-1706-9

Haussmann, B. I. G., Hess, D. E., Omanya, G. O., Reddy, B. V. S., Welz, H. G., \& Geiger, H. H. (2001). Major and minor genes for stimulation of seed germination in sorghum, and interaction with different Striga populations. Crop Science, 45, 1507-1512. https://doi.org/10.2135/cropsci2001.4151507x

Haussmann, B. I. G., Hess, D. E., Reddy, B. V. S., Mukuru, S. Z., Kayentao, M., Welz, H. G., \& Geiger, H. H. (2000b). Diallel studies on Striga resistance in sorghum. In B. I. G. Haussmann, D. E. Hess, M. L. Koyama, L. Grivet, H. F. W. Rattunde, \& H. H. Geiger (Eds.), Breeding for Striga resistance in cereals Workshop Proceeding (pp. 41-57). Margraf Verlag, Weikersheim, Germany.

Haussmann, B. I. G., Hess, E., Welz, H. G., \& Geiger, H. H. (2000a). Improved methodologies for breeding Striga-resistant sorghums. Field Crops Research, 66, 195-211. https://doi.org/10.1016/S0378-4290(00) 00076-9

Johnson, H. W., Robinson, H. F., \& Comstock, R. E. (1955). Estimation of genetic and environmental variability in soybeans. Agronomy Journal, 47, 314-318. https://doi.org/10.2134/agronj1955.00021962004700070009x

Keneni, G., \& Jarso, M. (2009). Comparison of Two Approaches for Estimation of Genetic Variation for Two Economic Traits in Faba Bean Genotypes Grown under Waterlogged Verisols. East African Journal of Sciences, 3, 95-101. https://doi.org/10.4314/eajsci.v3i1.42793

Kountche, B. A., Hash, C. T., Dodo, H., Oumarou, L., Sanogo, M. D., Amadou, T., ... Haussmann, B. I. G. (2013). Development of a pearl millet Striga-resistant genepool: response to five cycles of recurrent selection under Striga-infested field conditions in West Africa. Field Crops Research, 154, 82-90. https://doi.org/10.1016/j.fcr.2013.07.008

Lane, J. A., Bailey, J. A., Butler, R. C., \& Terry, P. J. (1993) Resistance of cowpea [Vigna unguiculata (L.) Walp.] to Striga gesnerioides (Willd.) Vatke, a parasitic angiosperm. New Phytologist, 125(2), 405-412. https://doi.org/10.1111/j.1469-8137.1993.tb03893.x

Lush, J. L. (1949). Heritability of quantitative characters in farm animals. Hereditas 35(S1), $356-375$. https://doi.org/10.1111/j.1601-5223.1949.tb03347.x

Mulumba, N. N., \& Mock, J. J. (1978). Improvement of yield potential in the Eto Blanco maize (Zea mays L.) population by breeding for plant traits. Egyptian Journal of Genetics and Cytology, 7, 40-51.

National Research Council. (1993). Managing global genetic resources: Agricultural crop issues and policies. National Academies Press.

Obilana, A. B. (2004). Research process, dissemination and impacts. In M. C. S. Bantilan, U. K. Deb, C. L. L.Gowda, B. V. S. Reddy, A. B. Obilana, \& R. E. Evenson (Eds.), Sorghum genetic enhancement. Patancheru, Andhra Pradesh, India: International Crops Research Institute for the Semi-Arid Tropics. 
Omanya, G. O., Haussmann, B. I. G., Hess, D. E., Reddy, B. V. S., Kayentao, M., Welz, H. G., \& Geiger, H. H. (2004). Utility of indirect and direct selection traits for improving Striga resistance in two sorghum recombinant inbred populations. Field Crops Research, 89, 237-252. https://doi.org/10.1016/j.fcr. 2004.02.003

Press, M., Gurney, A. L., Frost, D. L., \& Scholes, J. D. (1996). How does the parasitic angiosperm Striga hermonthica influence host growth and carbon relations? In M. T. Moreno, J. I. Cubero, D. Berner, D. Joel, L. J. Musselman, \& C. Parker (Eds.), Advances in parasitic plant research (pp. 303-310). Sixth International Parasitic Weed Symposium, Cordoba, Spain.

Robert, O. J. (2011). Genetic analysis of Striga hermonthica resistance in sorghum (sorghum bicolor) genotypes in Eastern Uganda (Ph.D. Thesis, University of KwaZulu-Natal, Pietermaritzburg, South Africa). Retrieved from http://hdl.handle.net/10413/9981

Robinson, H., Comstock, R. E., \& Harvey, P. (1949). Estimates of heritability and the degree of dominance in corn. Agronomy Journal, 41, 353-359. https://doi.org/10.2134/agronj1949.00021962004100080005x

Rodenburg, J., \& Bastiaans, L. (2011). Host-plant defence against Striga spp.: Reconsidering the role of tolerance. Weed Research, 51, 438-441. https://doi.org/10.1111/j.1365-3180.2011.00871.x

Rodenburg, J., Bastiaans, L., Weltzien, E., \& Hess, D. E. (2005). How can field selection for Striga resistance and tolerance in sorghum be improved? Field Crops Research, 93, 34-50. https://doi.org/10.1016/j.fcr.2004. 09.004

Rodenburg, J., Cissoko, M., Kayongo, N., Dieng, I., Bisikwa, J., Irakiza, R., ... Scholes, J. D. (2017). Genetic variation and host-parasite specificity of Striga resistance and tolerance in rice: the need for predictive breeding. New Phytologist, 214(3), 1267-1280. https://doi.org/10.1111/nph.14451

Rooney, W. L. (2004). Sorghum improvement-Integrating traditional and new technology to produce improved genotypes. Advances in Agronomy, 83, 37-109. https://doi.org/10.1016/S0065-2113(04)83002-5

Satish, K., Gutema, Z., Grenier, C., Rich, P. J., \& Ejeta, G. (2012). Molecular tagging and validation of microsatellite markers linked to the low germination stimulant gene (lgs) for Striga resistance in sorghum [Sorghum bicolor (L.) Moench]. Theoretical and Applied Genetics, 124, 989-1003. https://doi.org/ 10.1007/s00122-011-1763-9

Senthilvel, S., Jayashree, B., Mahalakshmi, V., Sathish, K. P., Nakka, S., Nepolean, T., (2008). Development and mapping of simple sequence repeat markers for pearl millet from data mining of expressed sequence tags. BMC Plant Biology, 8, 119. 2229-8-119. https://doi.org/10.1186/1471-2229-8-119

Tadele, Z. (2017). Raising crop productivity in Africa through Intensification. Agronomy, 7, 22. https://doi.org/ 10.3390/agronomy7010022

Warkad, Y. N., Potdukhe, N. R., Dethe, A. M., Kahate, P. A., \& Kotgire, R. R. (2008). Genetic variability, heritability and genetic advance for quantitative traits in sorghum germplasm. Agricultural Science Digest, 28, 165-169.

Yoder, J. I., \& Scholes, J. D. (2010). Host plant resistance to parasitic weeds; recent progress and bottlenecks. Current Opinion in Plant Biology, 13(4), 478-484. https://doi.org/10.1016/j.pbi.2010.04.011 


\section{Appendix A}

Means for grain yield and its agronomic components of the 25 sorghum accessions evaluated across environments

\begin{tabular}{|c|c|c|c|c|c|c|c|c|c|c|}
\hline Accession & $\begin{array}{l}\text { Head } \\
\text { Count }\end{array}$ & $\begin{array}{l}\text { Head } \\
\text { Weight } \\
(\mathrm{kg})\end{array}$ & $\begin{array}{l}\text { Grain } \\
\text { Weight } \\
(\mathrm{Kg})\end{array}$ & $\begin{array}{l}\text { Grain } \\
\text { Yield } \\
(\mathrm{kg} / \mathrm{ha})\end{array}$ & $\begin{array}{l}\text { Days } \\
\text { to } 50 \% \\
\text { flowering }\end{array}$ & $\begin{array}{l}\text { Plant } \\
\text { Height } \\
(\mathrm{cm})\end{array}$ & $\begin{array}{l}\text { Striga } \\
\text { Count at } \\
45 \text { DAS }\end{array}$ & $\begin{array}{l}\text { Striga } \\
\text { count at } \\
59 \mathrm{DAS}\end{array}$ & $\begin{array}{l}\text { Striga } \\
\text { count at } \\
73 \text { DAS }\end{array}$ & AUSNPC \\
\hline NGAA0311016 & 24.23 & 1.35 & 0.91 & 2698.39 & 92.07 & 279.10 & 1.14 & 1.49 & 1.55 & 38.94 \\
\hline NGOJMAY09009 & 23.40 & 0.98 & 0.65 & 1930.96 & 98.79 & 350.76 & 0.96 & 1.17 & 1.39 & 32.26 \\
\hline NGSA07143 & 28.57 & 1.50 & 1.33 & 3958.64 & 97.05 & 251.90 & 0.92 & 1.23 & 1.45 & 33.07 \\
\hline NGSA07103 & 12.90 & 1.21 & 0.67 & 1998.14 & 90.63 & 284.49 & 0.86 & 1.02 & 1.18 & 27.90 \\
\hline NGJD0511063 & 26.02 & 1.28 & 0.97 & 2898.24 & 102.53 & 323.23 & 0.67 & 0.97 & 1.14 & 25.52 \\
\hline NGAO1108001 & 22.13 & 1.08 & 0.56 & 1653.07 & 67.39 & 191.31 & 0.99 & 1.23 & 1.30 & 32.59 \\
\hline SAMSORG40 & 17.08 & 0.72 & 0.53 & 1589.17 & 80.45 & 180.62 & 0.65 & 0.88 & 1.00 & 23.18 \\
\hline SAMSORG14 & 29.95 & 1.87 & 1.42 & 4233.84 & 100.13 & 246.61 & 1.11 & 1.27 & 1.40 & 34.61 \\
\hline $\mathrm{N} 13$ & 18.34 & 0.87 & 0.72 & 2144.77 & 92.06 & 234.08 & 0.95 & 1.23 & 1.27 & 31.98 \\
\hline SRN39 & 17.52 & 0.90 & 0.57 & 1689.08 & 70.56 & 152.44 & 0.60 & 0.68 & 0.93 & 19.53 \\
\hline SRN15401 & 20.12 & 1.50 & 1.20 & 3570.55 & 98.41 & 321.14 & 0.87 & 1.22 & 1.30 & 31.57 \\
\hline Danyana & 24.75 & 1.95 & 1.37 & 4077.76 & 92.96 & 259.21 & 0.68 & 0.94 & 0.91 & 23.59 \\
\hline CSR-01 & 28.01 & 1.97 & 1.10 & 3276.64 & 107.96 & 229.10 & 1.00 & 1.37 & 1.52 & 36.01 \\
\hline CSR-02 & 22.67 & 1.49 & 1.27 & 3781.26 & 99.08 & 234.69 & 0.89 & 1.11 & 1.27 & 30.02 \\
\hline SAMSORG39 & 29.52 & 1.34 & 0.90 & 2684.54 & 86.59 & 157.63 & 0.98 & 1.20 & 1.34 & 32.28 \\
\hline White kaura & 18.91 & 1.04 & 0.71 & 2126.13 & 81.16 & 228.86 & 0.96 & 1.11 & 1.33 & 30.86 \\
\hline MaceDaKunya & 27.99 & 1.95 & 1.33 & 3971.42 & 94.56 & 174.41 & 0.82 & 1.04 & 1.20 & 27.95 \\
\hline Wassa & 23.29 & 0.82 & 0.59 & 1758.20 & 79.18 & 216.71 & 1.36 & 1.48 & 1.61 & 40.84 \\
\hline Malisor84-7 & 23.68 & 0.82 & 0.57 & 1686.22 & 67.95 & 194.53 & 1.14 & 1.40 & 1.44 & 36.91 \\
\hline CSM63 & 23.78 & 0.85 & 0.63 & 1871.81 & 89.95 & 198.18 & 0.79 & 1.00 & 1.09 & 26.44 \\
\hline Grinkan & 31.82 & 1.56 & 0.89 & 2640.10 & 87.47 & 136.09 & 0.80 & 1.01 & 1.09 & 26.67 \\
\hline Framida & 26.28 & 1.25 & 0.77 & 2292.50 & 78.28 & 187.06 & 0.86 & 1.17 & 1.26 & 30.54 \\
\hline Sepon82 & 28.82 & 1.07 & 0.70 & 2083.17 & 94.09 & 130.50 & 0.57 & 0.63 & 0.92 & 18.63 \\
\hline Sariaso14 & 14.05 & 0.64 & 0.36 & 1065.60 & 86.52 & 192.09 & 0.90 & 1.05 & 1.09 & 27.90 \\
\hline Seguetana & 16.13 & 0.54 & 0.49 & 1454.98 & 78.50 & 263.66 & 1.03 & 1.12 & 1.31 & 31.30 \\
\hline
\end{tabular}

\section{Copyrights}

Copyright for this article is retained by the author(s), with first publication rights granted to the journal.

This is an open-access article distributed under the terms and conditions of the Creative Commons Attribution license (http://creativecommons.org/licenses/by/4.0/). 